\title{
Bakteri Simbion Karang Lunak Sinularia sp. sebagai Agen Antibakteri
}

\section{Sekar Widyaningsih* dan Nor Sa'adah}

\author{
Program Studi Oseanografi, Fakultas Teknik dan Ilmu Kelautan, Universitas Hang Tuah \\ Jl. Arif Rahman Hakim 150 Surabaya 60111 \\ Email : sekar.widyaningsih@hangtuah.ac.id
}

\section{Abstract \\ Symbiotic bacteria of soft-coral Sinularia sp. as antibacterial agent}

The disease caused by bacterial pathogen infection has become a major problem in the world of health. Therefore, it needs new bioactive compond to resolve that problem. Symbiotic bacteria of softcoral are one promising source. This is because symbiotic bacteria of softcoral have the same bioactive compounds as their host. Symbiotic bacteria were isolated from softcoral Sinularia sp. that collected from Tanjung Gelam Waters, Karimunjawa Jepara. The symbiotic bacteria screened for antibacterial activity against E.coli, Proteus sp., Enterobacter sp. and S. aureus with diffution agar method. One of ten symbiotic bacteria was active against, SNTGA 5, with inhibition zone $9.067 \pm 0.305 \mathrm{~mm}$ against $E$ coli, $8.533 \pm 0.416 \mathrm{~mm}$ against $S$. aureus, $9.067 \pm 0.058 \mathrm{~mm}$ against Enterobacter sp., dan $9.1 \pm 0.557 \mathrm{~mm}$ against Proteus sp.. The molecular identification based on partial I6S DNA, that active isolate was closely related to Pseudomonas stutzeri.

Keywords: Antibacterial, Sinularia sp., symbiontic bacterial, PCR I6S DNA, Pseudomonas stutzeri

\begin{abstract}
Abstrak
Penyakit akibat infeksi bakteri patogen telah menjadi masalah utama dalam dunia kesehatan. Oleh karenanya, diperlukan bahan aktif baru guna mengatasi masalah tersebut. Bakteri simbion karang lunak merupakan salah satu sumber yang menjanjikan. Hal ini karena bakteri simbion karang lunak memiliki senyawa bioaktif yang sama dengan inangnya. Bakteri simbion diisolasi dari karang lunak Sinularia sp. yang dikoleksi dari Perairan Tanjung Gelam Karimunjawa Jepara. Bakteri simbion diuji aktivitasnya terhadap E.coli, Proteus sp., Enterobacter sp. dan S. aureus dengan metode difusi agar. Satu dari 10 bakteri simbion memiliki aktivitas antibakteri, SNTGA5, dengan besar zona hambat $9.067 \pm 0.305 \mathrm{~mm}$ terhadap $E$ coli, $8.533 \pm 0.416 \mathrm{~mm}$ terhadap S. aureus, $9.067 \pm 0.058 \mathrm{~mm}$ terhadap Enterobacter sp., dan $9.1 \pm 0.557 \mathrm{~mm}$ terhadap Proteus sp.. Identifikasi molekuler dilakukan dengan menggunakan PCR 16S DNA, dimana isolat yang aktif memiliki memiliki kekerabatan terdekat dengan Pseudomonas stutzeri.
\end{abstract}

Kata kunci : Antibakteri, Sinularia sp., PCR 16S DNA, Pseudomonas stutzeri

\section{PENDAHULUAN}

Salah masalah kesehatan yang disebabkan oleh bakteri patogen E. coli, Proteus sp., Enterobacter sp. dan S. aureus adalah foodborne infections dan waterborne infections (Thielman dan Guerrant, 2004). Penggunaan obat yang tidak tepat dan pengobatan yang tidak tuntas pada suatu penyakit akan menyebabkan bakteri patogen menjadi resisten (Radjasa et al., 2007a).

Invertebrata laut seperti karang lunak, diketahui memiliki kandungan metabolit sekunder yang melimpah, sehingga menjadi target eksplorasi sumber senyawa bioaktif alami (Radjasa, et al., 2007b; Thiel dan Imhoff, 2003). Untuk dimanfaatkan sebagai obat diperlukan jumlah yang besar, dan hal tersebut menjadi masalah tersendiri bagi 
ketersediaan karang lunak di alam. Diperlukan alternatif lain, seperti pemanfaatan bakteri simbionnya. Seperti yang diungkapkan oleh Burgess et al., (2003), bahwa mikroorganisme simbion mampu mensistesa metabolit sekunder seperti organisme inangnya. Oleh karenanya, bakteri yang bersimbiosis dengan Sinularia sp. dapat memberi kontribusi sebagai sumber alternatif baru, khususnya sebagai antibakteri. Seperti Paenibacillus campinasensis yang diisolasi dari karang lunak Lobophytum sp. yang memiliki aktivitas antibakteri $E$. coli dan S. aureus (Murti dan Radjasa, 2012). Maka dilakukanlah penelitian mengenai aktivitas antibakteri dari bakteri simbion karang lunak Sinularia sp. ini.

\section{MATERI DAN METODE}

Materi yang digunakan dalam penelitian ini antara lain bakteri yang diisolasi dari Sinularia sp. dari Perairan Tanjung Gelam, Karimunjawa, Jepara. Kultur bakteri patogen E.coli, S.aureus, Enterobacter sp., dan Proteus sp. sebagai bakteri uji.

\section{Kultur dan Isolasi bakteri simbion}

Kultur dan isolasi bakteri simbion dari karang lunak Sinularia sp. yang diperoleh dari Perairan Tanjung Gelam Karimunjawa Jepara dilakukan menggunakan media Zobell 2216E, dengan metode streak, dan diinkubasi selama 2X24 jam (Madigan et al. 2000; Radjasa et al., 2007a).

\section{Antibacterial test}

Antibacterial test dilakukan dengan metode difusi agar. Kultur setiap bakteri uji patogen pada fase logaritma distreak di

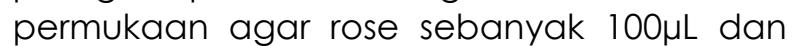
didiamkan selama 10-15 menit. Kultur bakteri simbion yang juga fase logaritma dimasukkan pada paperdisk dan ditempelkan di atas agar rose berbakteri patogen. Hasil uji diinkubasi selama 1×24 jam, dan dilakukan pengukuran zona bening. Aktivitas antibakteri ditentukan dengan adanya zona bening di sekitar koloni bakteri (Radjasa et al., 2007a).

\section{Amplifikasi PCR dan Sequensing DNA}

Amplifikasi DNA dilakukan dengan menggunakan metode Radjasa et al. (2007b).
Genomik DNA bakteri yang memiliki aktivitas antibateri diisolasi dari materi sel yang diambil dari agar di cawan petri. Materi tersebut dilarutkan dalam air steril dan dibekukan pada suhu $-80^{\circ} \mathrm{C}$ dan dipanaskan pada suhu $95^{\circ} \mathrm{C}$ sebanyak lima kali ulangan. Amplifikasi PCR 16S RNA bakteri simbion Sinularia sp., purifikasi produk PCR dan analisis sekuensing dilakukan berdasarkan metode Radjasa et al. (2007c). Hasil data sekuensing dicocokkan dengan data homologi dalam BLAST database.

\section{Screening PCR - NRPS}

Amplifikasi gen Non-Ribosomal Peptide Synthetases (NRPS) dengan menggunakan primer A2gamF (5' AAG GCN GGC GSB GCS TAY STG CC 3') dan A3gamR (5' TTG GGB IKB CCG GTS GIN CCS GAG GTG 3') (Radjasa et. al., 2007C). Amplifikasi DNA dilakukan dengan mesin DNA thermal cycler (MyCycler, BioRad) dengan metode Radjasa et al., (2007b).

\section{Analisa Sekuensing DNA}

Analisis sekuen DNA isolat bakteri terbaik kemudian dibandingkan dengan sekuen DNA pada basis data (database) DNA. Penelusuran dilakukan dengan menggunakan internet melalui program pelacakan database Basic Local Alignment Search Tool (BLAST) pada National Center for Biotechnology Information, National Institute for Health, USA (www.ncbi.nlm.nih.gov) (Altschul et al., 1997; Radjasa et al., 2008).

\section{HASIL DAN PEMBAHASAN}

Terdapat sepuluh bakteri simbion dari karang lunak Sinularia sp, dimana hanya satu isolat bakteri saja (SNTGA5) yang ditemukan mampu menghambat pertumbuhan empat bakteri patogen (Tabel 1). Identifikasi molekuler isolat bakteri simbion aktif dilakukan berdasarkan 16S rDNA, dan hasil menunjukkan isolat memiliki kekerabatan dengan Pseudomonas stutzeri (Tabel 2). Hasil screening menunjukkan isolat bakteri aktif mampu mengamplifikasi fragmen gen NRPS (Gambar 1). Masalah bakteri patogen yang berubah resisten terhadap berbagai antibiotik menjadi salah satu masalah utama di bidang kesehatan. Hal tersebut dapat menyebabkan meningkatnya mortalitas, 
morbilitas dan biaya kesehatan (Cohen, 1994; Wang, 2003). Seperti menurut Thielman dan Guerrant (2004), infeksi diare disebabkan oleh foodborne infections dan waterborne infections yang disebabkan bakteri Salmonella spp, Campylobacter jejuni, Staphyilococcus aureus, Bacillus cereus, Clostridium perfringens dan Enterohemorrhagic Escherichia coli (EHEC).

Organisme laut yang berasal sari ekosistem terumbu karang menjadi sumber yang menarik dan penting dalam produksi natural product. Hal tersebut dikarenakan mereka memproduksi berbagai senyawa bioaktif guna menunjang aktivitas mereka di alam (Sulistiyani et al., 2010). Invertebrata laut yang juga bagian dari ekosistem terumbu karang diketahui kaya akan senyawa metabolit yang berpotensi untuk dikembangkan (Faulkner, 2001).

Pemanfaatan produk alam secara langsung menjadi masalah lain. Hal tersebut, dikarenakan suplai yang terbatas, sehingga digantikan bakteri simbionnya. Seperti menurut Perez Matos et al. (2007), bakteri yang bersimbiosis mampu mensintesa senyawa bioaktif yang mirip dengan inangnya. Pada beberapa penelitian bakteri simbion invertebrata laut, khususnya karang lunak terbukti mampu memproduksi senyawa metabolit sekunder yang mirip dengan inangnya, seperti bakteri simbion Sinularia polydactyla mempunyai aktivitas antibakteri terhadap Streptococcus equi subsp. Zooepidemicus (Radjasa et al., 2007c).

Penelitian bakteri simbion Sinularia sp. menunjukkan adanya aktivitas antibateri terhadap empat bakteri patogen, E. coli, Proteus sp., Enterobacter sp. dan S. aureus, dengan adanya zona hambat (Tabel 1).

Hasil DNA sekuensing isolat SNTGA5 yang mampu menghambat E. Coli, S. aureus, Proteus sp., dan Enterobacter sp. memiliki kesamaan homologi sebesar 100\%, dan berkerabat dengan Pseudomonas stutzeri (Tabel 2). Seperti pada Uzair et al. (2007), yang mengisolasi bakteri Pseudomonas stutzeri dari saluran usus ikan Ribbon (Desmodema sp.) mempu menghambat bakteri patogen S. aureus. Fragmen gen NRPS berhasil diampliikasi dari bakteri SNTGA5 (Gambar 1). Oleh karenanya isolat SNTGA5 diduga termasuk kelompok peptida yang dihasilkan melalui jalur nonribosomal. Seperti bakteri yang berasosiasi dengan karang lunak Sinularia polydactyla, TASC.16 yang menghambat Streptococcus equi yang juga ditemukan berfragmen NRPS (Isrina, 2008).

Tabel 1. Aktivitas antibakteri bakteri simbion karang lunak Sinularia sp. terhadap pathogen

\begin{tabular}{ccccc}
\hline \multirow{2}{*}{ No. Isolat bakteri simbion } & \multicolumn{4}{c}{ Diameter zona hambat $(\mathrm{mm})$} \\
\cline { 2 - 5 } & E. coli & S. aureus & Enterobacter sp. & Proteus sp. \\
\hline SNTGA5 & $9.067 \pm 0.305$ & $8.533 \pm 0.416$ & $9.067 \pm 0.058$ & $9.1 \pm 0.557$ \\
\hline
\end{tabular}

Tabel 2. Identifikasi molekular isolate bakteri

\begin{tabular}{llllll}
\hline No. & Kode bakteri & Panjang & Kekerabatan terdekat & Homologi & No. akses \\
\hline 1 & SNTGA5 & 811 & Pseudomonas stutzeri & $100 \%$ & JF727659.1 \\
\hline
\end{tabular}

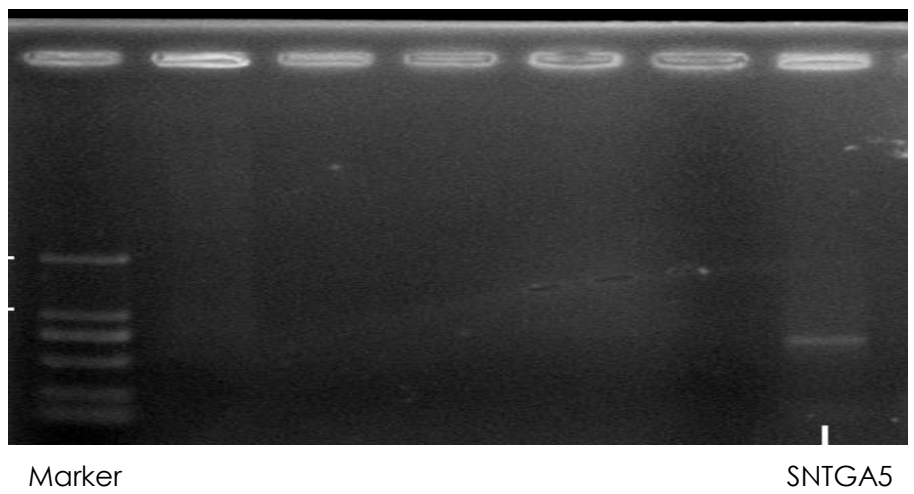

Gambar 1. Hasil amplifikasi gen NRPS isolat bakteri SNTGA 5 
Peptida nonribosomal dapat menghasilkan berbagai macam molekul peptide berantai asam lemak, asam amino non proteinogenik, asam karboksil, cincin heterosiklik dan asam amino yang termodifikasi. Strukturnya juga dapat bercabang atau siklik, dan masih dapat teroksidasi atau tereduksi (Marahiel and Finking, 2004).

\section{KESIMPULAN}

Bakteri yang berasosiasi dengan karang lunak Sinularia sp. yang mempunyai aktivitas antibakteri terhadap empat bakteri patogen E. coli, Proteus sp., Enterobacter sp. dan S. aureus. adalah Pseudomonas stutzeri. Selain itu, bakteri simbion ini juga diduga termasuk kelompok peptide yang mampu mengaplifikasi fragmen gen NRPS. Diharapkan penelitian ini digunakan sebagai solusi awal dalam masalah penanganan bakteri patogen, dan masalah suplai ketika mencari bahan bioaktif dari alam.

\section{UCAPAN TERIMAKASIH}

Ucapan terimakasih disampaikan kepada Prof. Ocky Karna Radjasa yang telah memberi dana untuk penelitian ini.

\section{DAFTAR PUSTAKA}

Altschul, S.F., Madden, T.L., Schäffer, A.A., Zhang, J., Zhang, Z., Miller, W. \& Lipman, D.J. 1997. Gapped BLAST and PSI-BLAST: a new generation of protein database search programs. Nucleic acids Res. 25(17):3389-3402.

Burgess, J.G., Boyd, K.G., Armstrong, E., Jiang, Z., Yan, L., Berggren, M. \& Adams, D.R. 2003. The development of a marine natural product-based antifouling paint. Biofouling. 19(S1):197-205.

Cohen, M.L. 1994. Antimicrobial Resistance: Prognosis for Publichealth. Trends Microbiol . 2 : 422-425.

Faulkner, D.J. 2001. Marine natural products. Nat. Prod. Rep. 18(1):1R-49R.

Finking, R., \& Marahiel, M.A. 2004. Biosynthesis of Nonribosomal Peptides. Annu. Rev. Microbiol., 58:453-488. DOI : 10.1146/ annurev.micro.58.030603.123615

Isrina, S.O.S. \& Lammler, C. 2008. Antibacterial Property of Marine Bacterium pseudomonas sp. Associated with A Soft
Coral against Pathogenic Streptococcus equi subsp. Zooepidemi-cus J. Coast. Dev. 11 (3):113-120.

Madigan, M.T., Martinko, J.M. \& Parker, J. 2000. Brock Biology of Microorganisms. Prentice Hall. New Jersey.

Murti, P.D.B. \& Radjasa, O.K. 2012. Antibacterial Activity of Bacterial Symbiont of Soft Coral Lobophytum sp. against MDR Bacteria Escherichia coli and Staphyllococcus aureus. J. Coast. Dev. 15(3):297-302.

Radjasa, O. K., Kencana, D. S., Sabdono, A., Hutagalung, R. A., \& Lestari, E. S. 2007a. Antibacterial activity of marine bacteria associated with sponge Aaptos sp. against Multi Drugs Resistant (MDR) strains. J. Mat. Sains. 12(4):147-152.

Radjasa, O. K., Martens, T., Grossart, H. P., Brinkhoff, T., Sabdono, A., \& Simon, M. 2007b. Antagonistic Activity of a Marine Bacterium Pseudoalteromonas Iuteoviolacea TAB4. 2 Associated with Coral Acropora sp. J. Biol. Sci. 7(2):239246. DOI : 10.3923/jbs.2007.239.246

Radjasa, O. K., Salasia, S. I. O., Sabdono, A., Wiese, J., Imhoff, J. F., Lämmler, C., \& Risk, M. J. 2007c. Antibacterial activity of marine bacterium Pseudomonas sp. associated with soft coral Sinularia polydactyla against Streptococcus equi subsp. zooepidemicus. Int. J. Pharmacol. 3(2):170-174.

Radjasa, O.K., Sabdono A., Wiese, J. \& Imhoff, J.F. 2008. Coral as Source Of Bacteria With Antimicrobial Activity. J. Coast. Dev., $11(3): 121-130$.

Sulistiyani, Nugraheni, S.A., Khoeri, M.M., Sabdono, A. \& Radjasa, O.K. 2010. Antibacterial Activity of Bacterial Symbionts of Softcoral Sinularia sp. against Pathogenic Resistant Bacteria. J. Coast. Dev., 13(2):113-118.

Thiel, V., \& Imhoff, J.F. 2003. Phylogenic Identification of Bacteria with Antimicrobial Activities Isolated from Mediterranean Sponges. Biomol. Eng. 20(4-6):421-423.

Thielman, N.M, \& Guerrant, R.L. 2004. Acute Infectious Diarrhea. N. Engl. J. Med. 350 (1):38-47.

Wang, T.K.F. \& Ho, P.L. 2003. The Challenge of Antibiotic Resistance in Asia: Problems and Solutions. Med. Prog. 8:41-49. 